\title{
Peran Orang Tua Dalam Mendidik Anak Perspektif Muhammad Taqī Al- Falsafī; Tela'ah Kitab Al-Thifl Baina Al-Waratsah Wa Al-Tarbiyah
}

\author{
Wan Muhammad Fariq, ${ }^{1, *}$ Muhajir Darwis², Ika Kurnia Sofiani ${ }^{3}$, Ajeng Ninda Umar ${ }^{4}$ \\ ${ }^{1,2,3}$ Sekolah Tinggi Agama Islam Negeri Bengkalis, Indonesia \\ ${ }^{4}$ Sekolah Tinggi Ilmu Tarbiyah Tanggamus, Indonesia \\ "one.fariq1@gmail.com
}

\begin{abstract}
Abstrak
Penelitian ini mengkaji pemikiran muhammad taq̄̄ al-falsafī (1908-1998) tentang peran orang tua dalam mendidik anak. Beliau merupakan pemikir asal Iran yang sezaman dengan Ayatullah al-Khomeini. Penelitian studi kepustakaan ini dimaksud untuk mengetahui peran orang tua dalam mendidik anak beserta relevansinya terhadap pola asuh orang tua pada era modern. Data primer penelitian ini adalah kitab AlThifl Baina Al-Waratsah wa Al-Tarbiyah yang merupakan karyanya. Sedangkan data skunder diambil dari buku-buku dan artikel-artikel yang berkaitan dengan pembahasan. Untuk mencapai tujuan di atas, penelitian ini menggunakan metode: induktif, deduktif, komperatif, dan analisis isi. Berdasarkan hasil penelitian, dapat disimpulkan bahwa ada lima peran orang tua dalam mendidik anak yang dapat dikutip dari kitab tersebut. Di antaranya: jangan mengingkari janji dengan anak; melatih anak untuk bersikap jujur; memuliakan kepribadian anak; menumbuhkan keimanan pada diri anak; dan tidak berlebihan dalam mencintai anak. Konsep pemikiran Muhammad Taqi al-Falsafi masih diterapkan oleh para orang tua dalam mendidik anak dan masih relevan dalam pendidikan anak saat ini.
\end{abstract}

Kata kunci: anak; muhammad taqi al-falsafi; peran orang tua

\section{The Role Of Parents In Educing Children's Perspective Muhammad Taqī Al- Falsafī; Have The Book Of Al-Thifl Baina Al-Waratsah Wa Al-Tarbiyah}

\footnotetext{
Abstract

This study examines the thoughts of Muhammad Taqi al-Falsafi (1908-1998) regarding the role of parents in educating children. He is an Iranian thinker who is a contemporary of Ayatullah al-Khomeini. This literature study research is intended to determine the role of parents in educating children and their relevance to parenting styles in the modern era. The primary data of this research is the book Al-Thifl Baina Al-Waratsah wa Al-Tarbiyah which is his work. Meanwhile, secondary data were taken from books and articles related to the discussion. To achieve the above objectives, this research uses methods: inductive, deductive, comparative, and content analysis. Based on the research results, itcan be concluded that there are five roles of parents in educating children which can be quoted from the book. Among them: do not break promises with children; train children to be honest; glorify the child's personality; fostering faith in children; and not to love children too much. The concept of Muhammad Taqi al-Falsafi's thought is still applied by parents in educating children and is still relevant in children's education today.

Keywords: children; muhammad taqi al-falsafi; the role of parents
} 
Al Athfaal: Jurnal Ilmiah Pendidikan Anak Usia Dini

Vol.4 No.1 (2021) 106-123

p-ISSN : 2622-5484

http://ejournal.radenintan.ac.id/index.php/al-athfaal

e-ISSN : 2622-5182

Juni 2021

\section{PENDAHULUAN}

Menurut data yang dipaparkan oleh Nick Clark, pada tahun 2010 pendidikan setiap jenjang di Iran terus mengalami peningkatan dari 98,7\% kisaran umur 15-24 tahun dan 85\% dari populasi umum yang lebih dari umur 15 tahun (Saleh, 2015). Pada tahun 2018, sebagaimana dilansir berita dari media sputniknews bahwa Iran memimpin riset di bidang fisika, biologi, kimia dan administrasi bisnis. Ini menandakan Iran sangat serius mengembangkan IPTEK dan siap bersaing dengan negara manapun. Sehingga banyak orang asing yang ingin melanjutkan studi di negara tempat asal sahabat nabi Salman al-Farisi ini. Dilansir dari berita alamat tv, lebih dari 500 ribu anak pelajar asing menuntut ilmu di Iran (TV, 2018).

Dengan demikian, sistem pendidikan di Iran perlu dikaji guna melihat lebih jauh konsep yang dirumuskan para pemikir pendidikan di sana. Ini semua tidak lepas dari pendidikan yang ditanam sejak kecil. Faktor lingkungan keluarga dan masyarakat terhadap pendidikan anak sangat mempengaruhi perkembangan mereka. Pada akhirnya, mampu mencetak generasi intelektual yang luar biasa setiap zamannya. Inilah jalan yang ditempuh oleh Iran dengan menyiapkan generasi terbaik mulai sejak dini, yaitu dengan pendidikan.

Memperbincangkan tentang pendidikan anak tidak terselenggara dengan baik jika hanya menyerahkan kepada pihak sekolah. Justru orang tualah yang menjadi "sekolah pertama" bagi anak. Peran orang tua mempunyai peranan penting dalam tumbuh kembang pendidikan anak. Hasil penelitian yang dilakukan oleh Kurniati bahwa secara general peran orang tua yaitu sebagai pembimbing, pendidik, penjaga, pengembang dan pengawas (Kurniati et al., 2020). Selain itu, anak itu sejatinya berperilaku layaknya hewan, "manusia”nya sulit untuk berkembang. Jika ia dididik dalam sebuah lingkungan masyarakat, "manusia'nya akan berkembang. Dalam ajaran agama disebutkan, tanggung jawab orang tua adalah mendidik anak sebagaimana yang diperintahkan oleh Tuhannya (Warsono, 2017). Tanggung jawab orang tua dalam mendidik anak sangat besar dalam keluarga. Fungsi dan peran sebagai orang tua bukan hanya memenuhi kebutuhan fisik anak seperti sandang dan pangan saja, akan tetapi juga tidak kalah penting memberikan perhatian, bimbingan, arahan, motivasi, pendidikan dan penanaman nilai (Jailani, 2014).

Fenomena saat ini yang terjadi adalah masih banyak orang tua yang belum memahami perannya sebagai pendidik dalam keluarga. Apalagi bagi orangtua yang jarang berada di tengah 
Al Athfaal: Jurnal Ilmiah Pendidikan Anak Usia Dini

Vol.4 No.1 (2021) 106-123

p-ISSN : 2622-5484

http://ejournal.radenintan.ac.id/index.php/al-athfaal

e-ISSN : 2622-5182

Juni 2021

keluarga dikarenakan harus bekerja di luar. Mestinya pendidikan tersebut bukan hanya dibebankan ke sekolah saja, akan tetapi dapat dilakukan di rumah. Umar menjelaskan bahwa keberhasilan anak-anak tidak terlepas dari perang orang tua. Peran tersebut dapat diimpelementasikan melalui bimbingan kelangsungan belajar anak di rumah yang relevan terhadap program yang ditetapkan oleh sekolah. (Umar, 2015). Menurut hasil penelitian yang dilakukan oleh A'yun bahwa pelaksanaan homeschooling anak usia dini menyumbang dampak positif bagi kemampuan anak, baik akademik maupun non akademik (A'yun et al., 2015).

Menurut Ahmad Tafsir ada empat macam kemungkinan berkenaan dengan hal di atas: Pertama, orang tua yang banyak di rumah tetapi tidak melakukan pendidikan dengan cara yang benar. Kedua, orangtua banyak di rumah tetapi tidak menggunakan waktu yang banyak itu untuk mendidik anaknya. Ketiga, orangtua yang sedikit di rumah tetapi memanfaatkan waktu yang sedikit itu sebaik-baiknya. Keempat, orangtua yang jarang di rumah dan pertemuan yang sedikit itu tidak ia manfaatkan untuk mendidik anaknya dengan cara yang benar (Tafsir, 2013). Perjalanan seorang anak menuju kedewasaan dipengaruhi oleh berbagai faktor, di antaranya faktor alam dan lingkungan. Oleh karena itu, perlu adanya peran orangtua serta pihak lain, seperti guru dan masyarakat untuk membantu proses tersebut agar kedewasaan seorang anak tidak terhambat (Sutarman, 2016). Selain itu, keberhasilan pendidikan anak juga ditentukan latar belakang pendidikan orang tua. Hasil penelitian yang dilakukan oleh Hasiana, ddk menunjukkan bahwa orangtua dengan lulusan SD, SMP dan SMA serta Perguruan tinggi berada pada kategori baik (Hasiana, 2020).

Berkaitan dengan pendidikan anak di atas, seorang tokoh Iran bernama Muhammad Taqī al-Falsafī mencoba untuk menganalisis mengenai pendidikan anak yang ditulis dalam kitabnya $\mathrm{Al}$ Thifl Baina Al-Waratsah Wa Al-Tarbiyah (Anak Antara Gen dan Pendidikan). Dalam buku tersebut menjelaskan peran orangtua sangat berarti dalam mendidik seorang anak. Keberhasilan seorang nak sangat ditentukan pola asuh mereka sejak kecil. Dari pemikirannya penulis temukan relevansi terhadap fenomena yang terjadi saat ini. Masih banyak orangtua mengabaikan peran mereka dalam mendidik anak. Di antaranya: tidak menepati janji, mengajarkan kebohongan, dan berlebihan dalam mencintai anak. 
Al Athfaal: Jurnal Ilmiah Pendidikan Anak Usia Dini

Vol.4 No.1 (2021) 106-123

http://ejournal.radenintan.ac.id/index.php/al-athfaal

p-ISSN : 2622-5484

e-ISSN : 2622-5182

Juni 2021

Dalam bahasa Arab, penggunaan kata anak ada beberapa istilah yang digunakan: Pertama, Al-Thifl. Menurut Abu al-Haitsam anak dikatakan al-Thifl sejak ia lahir dari perut ibunya sampai ia mengalami mimpi basah (Manzur, n.d.). Kedua, Al-Walad. Kata al-Walad digunakan untuk menunjukkan anak laki-laki dan perempuan yang kuat. Terkadang terhimpun makna anak seperti murid, pelayan, anak yatim dan lain-lain (Nawwāb, 2002). Ketiga, Al-Ghulam. Di dalam kamus al-Munjid fi al-Lughah dijelaskan bahwa kata al-Ghulam berarti remaja yang sudah mulai tumbuh bulunya (Ma'luf, 2017). Dalam Undang-Undang Republik Indonesia Nomor 35 Tahun 2014 Tentang Perubahan atas Undang-Undang Nomor 23 Tahun 2002 Tentang Perlindungan anak, Pasal 1 dijelaskan bahwa "anak adalah seseorang yang belum berusia 18 (delapan belas) tahun, termasuk anak yang masih dalam kandungan"(Undang-Undang RI Nomor 35 Tahun 2014 Tentang Perlindungan Anak, 2014).

Pola asuh merupakan bentuk interaksi antara anak dan orang tua, interaksi tersebut meliputi ketercukupan kebutuhan fisik dan kebutuhan non fisik (Warsono, 2017). Selain itu pola asuh orangtua juga bisa diartikan sebagai perawat, pemelihara, pengajar, pendidik, pembimbing, pelatih terhadap anak (Sunarty, 2016). Baumrind menjelaskan bahwa ada tiga gaya pengasuhan anak:

Pertama, gaya otoritarian, memandang penting kontrol dan kepatuhan tanpa syarat. Mereka mencoba membuat anak menyesuaikan diri dengan serangkaian standar perilaku dan menhukum mereka secara membabi buta dan dengan keras atas pelanggaran yang dilakukannya. Mereka menjadi lebih terlepas (detached) dan kurang hangat dibandigkan orang tua lain. Anak mereka cenderung menjadi lebih tidak puas, menarik diri, dan tidak percaya kepada orang lain (Papalia, Diane E., 2008). Gaya ini merupakan gaya pengasuhan tradisional yang kita temukan hampir di seluruh dunia dan bisa kita lihat di sepanjang sejarah. Orangtua adalah atas dalam keluarga, dan apa yang mereka katakan harus dijalankan. Konsekuensinya bisa keras - hukuman fisik, gertakan verbal, pengurungan - meski hal ini juga bukan berarti tidak ada kasih sayang (Boeree, 2017). Namun menurut Donna Hancock Hoskins bahwa efek dari pola asuh ini tergantung pada komunitas tempat tinggal anak tersebut (Hoskins, 2014).

Kedua, gaya permisif, menghargai ekspresi diri dan regulasi diri. Mereka mungkin membuat beberapa permintaan dan mengizinkan anak untuk memonitor aktivitas mereka sendiri sebanyak mungkin. Jika mereka harus membuat aturan, maka mereka akan menjelaskan alasannya 
Al Athfaal: Jurnal Ilmiah Pendidikan Anak Usia Dini

pada anak-anak mereka. Mereka berkonsultasi dengan anak-anak tentang keputusan kebijakan dan jarang menghukum. Mereka hangat, tidak mengontrol, dan tidak menuntut. Anak prasekolah mereka cenderung tidak dewasa-sangat kurang control diri dan kurang eksplorasi (Papalia, Diane E., 2008). Dalam kasus ini, anak diperbolehkan melakukan apa saja yang mereka suka, dan orangtua turun tangan hanya pada situasi-situasi darurat. Walaupun kita melihat gaya ini pada sejumlah masyarakat primitive dengan lingkungan yang relatif aman dan damai, kita lebih sering melihatnya dalam masyarakat modern seperti saat ini (Boeree, 2017).

Ketiga, gaya autoritatif, menghargai individualitas anak tetapi juga menekankan batas sosial. Mereka memiliki keyakinan diri akan kemampuan mereka membimbing anak-anak, tetapi mereka juga menghormati indepedensi keputusan, ketertarikan, pendapat, dan kepribadian anak. Mereka mencintai dan menerima, tetapi juga menuntut perilaku yang baik, dan kokoh dalam mempertahankan standar, dan memiliki keinginan untuk menjatuhkan hukuman yang bijaksana dan terbatas ketika memang hal tersebut dibutuhkan, dalam konteks hubungan yang hangat dan suportif. Mereka menjelaskan logika di belakang tindakan mereka dan mendorong saling memberi secara verbal. Anak-anak mereka tampaknya merasa aman ketika mengetahui bahwa mereka dicintai dan dibimbing secara hangat. Anak-anak prasekolah dengan orang tua otoritatif cenderung independen,terkontrol, asertif, eksploratoris, dan berisi (Papalia, Diane E., 2008). Kendati anak diberi kebebasan dan diikutkan dalam pengambilan ketupusan keluarga, orangtua tetap saja orangtua. Aturan diterangkan dengan sangat jelas dan tidak pernah semena-mena, dan hukuman "setimpal dengan kesalahan", namun tidak kejam secara fisik dan psikologis. Para psikolog yakin bahwa gaya ini paling memungkinkan untuk mengarahkan anak pada perkembangan yang bagus, tentunya (Prawira, 2017).

Dari bermacam teori tentang gaya pengasuhan, menurut hasil penelitian yang dilakukan oleh Paloma Alonso-Stuck bahwa gaya pengasuhan yang integratif dan serba guna lebih disarankan guna mempermudah dalam beradaptasi untuk merubah sifat masyarakat kita (Alonso-Stuyck, 2019).

Penelitian ini bertujuan untuk mengetahui peran orang tua dalam mendidik anak menurut Muhammad Taqī al-Falsafī dan relevansi pemikirannya terhadap pola asuh orang tua saat ini. 
Al Athfaal: Jurnal Ilmiah Pendidikan Anak Usia Dini

Vol.4 No.1 (2021) 106-123

p-ISSN : 2622-5484

http://ejournal.radenintan.ac.id/index.php/al-athfaal

e-ISSN : 2622-5182

Juni 2021

Diharapkan kedepannya, dapat dijadikan pijakan guna mengembangkan teori-teori pendidikan Islam yang relevan dengan kajian pendidikan modern.

\section{METODOLOGI PENELITIAN}

Penelitian ini termasuk dalam jenis penelitian kepustakaan (Library reseach), karena data yang diteliti ada dua sumber, yaitu sumber utama dan sumber kedua. Sumber utama berupa dokumen, catatan, dan peninggalan langsung dari peristiwa-peristiwa atau catatan saksi mata. Sedangkan yang kedua (skunder) pikiran dari orang yang bukan pengamat (bukan saksi mata) juga berada antara peristiwa dan pemakai catatan. Ini bisa berupa artikel ensiklopedia dan review penelitian (Dantes, 2012).

Penelitian ini menggunakan metode: induktif, deduktif, komperatif, dan analisis isi (Content Analysis). Penelitian ini berusaha memaparkan pemikiran Muhammad Taqī al-Falsafī tentang peran orang tua dalam mendidik anak. Dari data yang diperoleh, kemudian dilakukan analisis interpretasi dengan menggunakan metode sebagaimana yang disebut di atas.

Sumber data perimer dalam penelitian ini adalah kitab Al-Thifl Baina Al-Waratsah Wa AlTarbiyah. Sedangkan data skunder diambil dari buku, jurnal, website yang berkaitan dengan pembahasan.

Adapun teknik analisis data dilakukan dengan menentukan jenis data dan menganalisa datadata yang ada di daam sumber-sumber rujukan secara mendalam dengan pendekatan dan metode yang tersebut di atas.

\section{HASIL PENELITIAN DAN PEMBAHASAN}

\section{Biografi Muhammad Taqī al-Falsafī}

Muhammad Taqi Falsafi lahir di sebuah keluarga yang taat beragama pada tanggal 11 April 1908 di Teheran. Ayahnya bernama Mohammad Reza Tonekaboni merupakan seorang guru di Tehran hawza. Muhammad Taqi mulai mulai muncul di publik ketika dia berusia 16 tahun.(Falsafi, 2020). Guru pendidikan sekolah dasar Muhammad Taqi Falsafi bernama Sheikh Mohammad Reza Tawfiq. Di sana ia belajar selama enam tahun tentang membaca, menulis, kedisiplinan dan Al-Qur'an hingga memperoleh ijazah pendidikan dasar. Setelah menyelesaikan 
Al Athfaal: Jurnal Ilmiah Pendidikan Anak Usia Dini

Vol.4 No.1 (2021) 106-123

p-ISSN : 2622-5484

http://ejournal.radenintan.ac.id/index.php/al-athfaal

e-ISSN : 2622-5182

Juni 2021

sekolah dasar, ia mulai mempelajari ilmu-ilmu keislaman di sekolah Haji Abul Fateh dan belajar matematika dan linguistik kepada Sheikh Mohammad Rashti dan mempelajari buku populer karangan Mirza Younes Qazvini. Di bidang Fiqh, beliau belajar dengan Sheikh Mohammad Ali Kashan, Abdullah Khan, Sheikh Mehdi, Mohammadi dan belajar dari ayahnya (Ayatollah Tonekaboni). Di samping itu, beliau juga mempelajari ilmu filsafat di bawah bimbingan Mirza Mahdi Ashtiani, Sheikh Ibrahim Zaidi (wafat. Sekitar 1358 H), Seyed Kazem Assar (meninggal $1353 \mathrm{H}$ ) dan Mirza Tahir Tonekaboni (meninggal pada $1320 \mathrm{H}$ ). Pada tahun $1301 \mathrm{H}$ atau $1302 \mathrm{H}$, beliau melakukan perjalanan ke Qom untuk mempelajari ilmu agama Islam dan hukum syariat serta pendidikan dengan Sheikh Abu al-Qasim Rabiei (penduduk asli Rudsar), seorang teman dari Ayatollah Tonekaboni. Perjalanan itu tidak berlangsung lebih dari beberapa bulan karena cuaca di Qom tidak mendukung dan beliau pun harus kembali ke Teheran. Beliau meninggal pada tanggal 18 Desember 1998. Makamnya terletak di kuil Shah-Abdol-Azim di Rey (Falsafi, 2020). Di antara karya-karya beliau adalah: Al-Syab bain al-'Aql wa al-'Athifah, Al-Thifl bain al-Waratsah wa alTarbiyah, Al-Qashash al-Tarbiyah, Al-Afkar wa al-Raghabat bain Syuyukh wa al-Syabab, AlAkhlaq min Manzur al-Ta'ayusy wa al-Qayim al-Insaniyah, Ayat al-Kursi Nida' al-Tawhid alSamawi, Ma'ad bain al-Ruh wa al-Jasad, Al-Bayan wa Fann al-Khitabah dan Khurafat Azaliyat al-Madah

\section{Pemikiran Muhammad Taqī al-Falsafī Tentang Peran Orang Tua dalam Pendidikan Anak}

Di antara pemikiran Muhammad Taqī al-Falsafī dalam kitab al-Thifl Baina al-Waratsah wa al-Tarbiyah dapat kita lihat sebagai berikut:

1. Jangan mengingkari janji dengan anak

Muhammad Taqī al-Falsafī menjelaskan:

"Dalam rangka menghidupkan "berpegang teguh pada janji" dalam masyarakat, maka semua lapisan masyarakat harus mampu menanamkan sifat ini pada diri anak sejak dini. Wajib diajarkan kepada mereka pelajaran yang sangat berharga ini baik dalam teori maupun praktik sehingga tertancap di dalam diri mereka. Anak-anak diajarkan sebuah gambaran yang mereka mampu menemukan bahwa menepati janji merupakan kewajiban. Mereka tidak boleh mengingkari janji saja bahkan tidak diperkenankan pemikiran rusak ini terlintas di pikiran mereka. Pendidikan ini tidak akan berhasil kecuali pada lingkungan yang bersih dan steril yang dipersiapkan untuk anak. Lingkungan yang tidak mengenal dengan ingkar janji dan berbohong. Sesungguhnya anak menjadikan seluruh perkataan yang didengarnya atau prilaku 
Al Athfaal: Jurnal Ilmiah Pendidikan Anak Usia Dini

Vol.4 No.1 (2021) 106-123

p-ISSN : 2622-5484

http://ejournal.radenintan.ac.id/index.php/al-athfaal

e-ISSN : 2622-5182

Juni 2021

yang dilihatnya. Baik perilaku itu shalih atau rusak. Itulah yang menjadi contoh yang dijalani dalam kehidupannya. Di dalam lingkungan keluarga akan mudah mempengaruhi sebelum lainnya disebabkan prilaku kedua orang tua." (Al-Falsafī, 2017).

Pendapat ini selaras dengan yang dijelaskan oleh Mansur dalam bukunya "Pendidikan Anak Usia Dini dalam Islam”. Ia menjelaskan:

"Dalam benak anak, dalam otak kecil dan lembut pada diri anak, tidak sedikitpun bersemayam buruk sangka terhadap kalian. Dengan amat lugu, mereka mempercayai kalian, apa yang kalian ucapkan adalah benar dan pasti. Dengan demikian, kalian harus menjaga dan memperhatikan diri kalian untuk senantiasa menjaga mereka, sehingga mereka akan meniru dan meneladani perbuatan dan ucapan kalian. Kedua orang tua harus memperlakukan anak-anak dengan penuh kejujuran. Hendaklah ditanamkan suatu keyakian dalam benak anak bahwa janji dan hukuman terhadap mereka merupakan sebuah kenyataan dan pasti akan dijalankan. Adanya keyakinan itu justru akan memberikan ketenangan jiwa dan pikiran, baik bagi para pengasuh dan Pembina, maupun anak-anak itu sendiri (Mansur, 2014).”

Kita tahu bahwa tindakan mengingkari janji kepada anak memberikan efek buruk pada perkembangan otak anak. Karena di dalam diri anak tertanam bahwa orang tuanya sering melakukan kebohongan kepada mereka. Kebohongan yang terus menerus dari ketidaktepatan janji kepada anak mengakibatkan ketidakpercayaan anak terhadap orang tua dan mereka pun mengikutinya. Hasil riset terbaru dari data 377 tanggapan orang dewasa muda dari Singapura yang melaporkan keterpaparan masa kanak-kanak mereka terhadap pengasuhan dengan berbohong, perilaku menipu mereka saat ini terhadap orang tua, dan penyesuaian psikososial mereka (Setoh et al., 2019). Penelitian tersebut menjelaskan bahwa, sikap ketidakjujuran mereka saat ini disebabkan didikan orang tua mereka yang sering menipu mereka sejak kecil. Untuk itu, menepati janji terhadap anak harus ditanamkan sejak kecil sebagai upaya tindakan preventif ketika mereka dewasa kelak.

Sejatinya seorang anak bagaikan kertas putih. Orang tuanya lah yang bisa membentuk kepribadiannya. Bersikap jujur atau suka berbohong ditentukan oleh didikan orang tua terhadap mereka sejak lahir. Rasulullah SAW bersabda: Telah menceritakan kepada kami (Adam), telah menceritakan kepada kami (Ibnu Abu Zi'bin) dari (al-Zuhri) dari (Abu Salamah 
Al Athfaal: Jurnal Ilmiah Pendidikan Anak Usia Dini

bin Abd al-Rahman) dari (Abu Hurairah) radhiyallahu 'anhu berkata: Rasulullah SAW bersabda: "Setiap anak bayi tidak dilahirkan (ke dunia ini) melainkan ia berada dalam kesucian (fitrah). Kemudian kedua orang tuanyalah yang akan membuatnya menjadi Yahudi, Nasrani, ataupun Majusi -sebagaimana hewan yang dilahirkan dalam keadaan selamat tanpa cacat. Maka, apakah kalian merasakan adanya cacat?” (Al-Bukhārī, 1979). Dalam pandangan Imam al-Ghazali bahwa melatih anak merupakan hal yang amat penting. Sesungguhnya anak merupakan amanah kedua orangtuanya. Hatinya yang bersih adalah subtansi jiwa atau karakter, tidak ada pola dan bentuk di dalamnya. Hati tersebut mudah menerima setiap pola yang membentuk dan cenderung mengikuti apa yang membentuknya. Jika sudah terhabituasi dengan kebaikan dan diajarkan kepadanya, maka ia tumbuh seperti demikian. Ia mendapat kebahagiaan di dunia dan akhirat. Tentunya, kedua orang tua dan pendidiknya mendapat ganjaran yang setimpal. Begitu juga sebaliknya, jika ia terhabituasi dengan keburukan, maka ia dilalaikan sebagaimana kelalaian hewan, ia celaka dan rusak. Dosa juga ditanggung oleh pendidik dan orangtuanya (Al-Ghazālī, 2011).

Muhammad Taqī al-Falsafī sebagaimana yang telah dijelaskan di atas mengingatkan bahwa betapa pentingnya membentuk karakter anak dengan menepati janji kepada mereka. Untuk mewujudkannya harus ditanam dalam lingkungan keluarga dan masyarakat. Menurut hasil penelitian Kanggiesser, dkk, dengan meneliti anak usia 3-5 tahun dengan sample 278 orang didapatkan bahwa prilaku prososial, anak kecil merasakan kewajiban normatif untuk menetapi janji mereka dan mengharapkan orang lain juga untuk menepati janji mereka(Kanngiesser et al., 2017).

2. Melatih anak untuk bersikap jujur

Berkaitan dengan hal tersebut, Muhammad Taq̄i al-Falsafī menjelaskan:

"Salah satu kewajiban kedua orang tua adalah melatih anak, yakni menumbuhkan fitrah kejujuran. Kedua orang tua harus mampu bersikap dalam lingkungan keluarga yang menjadikan anak terbiasa jujur dan istiqomah. Mereka tidak boleh berpaling kepada jalan kebohongan. Hal ini merupakan pekerjaan terberat dalam menumbuhkan sikap-sikap pada anak. Untuk mencapai tujuan ini harus dalam pengawasan baik dalam teoritis maupun praktis." (Al-Falsafî, 2017). 
Al Athfaal: Jurnal Ilmiah Pendidikan Anak Usia Dini

Vol.4 No.1 (2021) 106-123

p-ISSN : 2622-5484

http://ejournal.radenintan.ac.id/index.php/al-athfaal

e-ISSN : 2622-5182

Juni 2021

Musthafa al-Ghalāyaini menjelaskan bahwa integritas merupakan nilai yang melekat pada diri orang berkeinginan, tidak mudah berubah antara dirinya dan realitas dengan apa yang mereka katakan (Al-Ghalāyaini, 1953). Hāfizh Hasan al-Mas'udi dalam kitab Taysir alKhalāq menerangkan bahwa faktor-faktor kejujuran di antaranya adalah akal, agama dan harga diri. Akal, dikarenakan akal mengetahui asas manfaat kejujuran dan kemudharatan (bahaya) kebohongan. Dirinya tidak akan rela terhadap kemudharatan, maka ia akan berpengang teguh kepada kejujuran. Dikarenakan agama menyeru terhadap kejujuran dan mencegah dari kebalikannya (kebohongan). Begitu juga dengan harga diri karena dirinya tidak akan menerima kecuali kejujuran. Karena kejujuran menuntut agar memperindah dalam segala tindakan, tidak memperindah kebohongan (Al-Mas'udi, n.d.).

Muhammad Taqī al-Falsafī menjelaskan faktor-faktor yang menyebabkan kebohongan di antaranya:

a. Tidak proposional dalam anjuran untuk beribadah

"Sebagian orang tua berasumsi bahwa wajib mendidik anak dengan pendidikan agama, akan tetapi melebihi kemampuan mereka. Mereka dibebankan untuk melaksanakan sunah-sunah, qiyam al-lail, membaca alQur'an dan do'a-do'a ma'tsurah. Orang tua beranggapan mereka harus melakukan itu semua dengan baik. Mereka mengatakan kepada anak: Jangan lupa membaca juz al-Qur'an ini setelah shalat subuh! Jangan tinggalkan do'a ini pada malam Jum'at! Baca zikir si Fulan sebanyak 1000 kali satu hari dan lain-lain. Mereka lupa bahwa beban yang berat ini bukan hanya tidak disenangi dalam ajaran Islam saja. Bahkan anak dengan tugas ini menjadikan mereka memandang agama dengan pandangan yang hina. Orang tua mengobarkan api yang jauh dari Islam di dalam hati anak. Ini mengakibatkan kesulitan bagi anak, melaksanakan seluruh sunah-sunah dan ibadah sunah secara berkelanjutan yang tidak biasa dilakukan. Pada sisi yang lain, anak takut jika orang tua mereka membencinya dan berhatihati atas ketidaknyamanan kedua orang tua mereka. Oleh sebab itu, anak akan berlindung dengan kebohongan. Ketika anak tidur sampai waktu subuh, dia akan mencoba membuat orang tuanya senang dan berbohong dengan mengaku telah qiyam al-lail sampai waktu subuh, shalat beberapa raka'at dan membaca al-Qur'an dan lain-lain. Kedua orang tua baik secara sisi teoritis dan agamis harus proposional terhadap anak. Jangan membebani mereka di atas kemampuan mereka. Karena takut akan kemarahan orang tua dan mencoba menyembunyikan kemalasan dan ketidakmampuan. Ketika ia tidak mampu melaksanakan tugas yang di atas 
Al Athfaal: Jurnal Ilmiah Pendidikan Anak Usia Dini

Vol.4 No.1 (2021) 106-123

p-ISSN : 2622-5484

http://ejournal.radenintan.ac.id/index.php/al-athfaal

e-ISSN : 2622-5182

Juni 2021

kemampuannya ia akan senantiasa berlindung di balik topeng kebohongan. Tindakan yang berulang-ulang ini menjadikannnya seorang hipokrit. Dapat disimpulkan bahwa salah satu faktor yang membiasakan anak berbohong yaitu membebaninya dan memaksanya dengan tugas-tugas yang di atas kemampuannya (Al-Falsafī, 2017).

b. Suka mencela anak

Faktor lain yang membiasakan anak berbohong adalah celaan dan hinaan. Kedua orang tua wajib mendidik anak relevan dengan pendidikan agama agar dapat menghormati kepribadian anak. Topik ini salah satu masalah yang penting dalam pembahasan pendidikan. Sesungguhnya anak yang lalai dari perhatian anggota keluarga dan tidak dihargai oleh orang lain, mereka terasa terhina, perbuatan tersebut menjadikan mereka terhina atau terkadang menipu mereka dan memarahi mereka tanpa pembelaan. Dengan kata lain, berprilaku bersama mereka dan anak terasa terhina. Mereka hanya mengetahui bahwa anggota keluarga menghina dan tidak meganggap mereka. Pada akhirnya mereka berpikir untuk balas dendam agar mereka dihargai. Oleh sebab itu sifat-sifat tercela akan tampak pada diri mereka secara gradual. Bahkan mengakibatkan perbuatan yang berbahaya (Al-Falsafî, 2017).

Oleh sebab itu, orang tua hendaknya memperlakukan sama terhadap seluruh anaknya, tanpa membedakan antara satu dengan lainnya dalam hal makanan, pakaian, pemberian, cinta dan apresiasi (M. M. Mursī, 1987).

c. Takut hukuman

Mayoritas manusia ketika berada dalam pemetintahan otoriter melakukan kebohongan karena takut terhadap hukuman yang berat dan tindakan yang tidak manusiawi yang muncul dari para hakim. Begitu juga anak-anakyang berada dalam keluarga yang kedua orang tuanya acapkali menghukumi, mereka juga melakukan kebohongan.

Sesungguhnya obat kebohongan ini cukup dengan kelembutan orang tua dalam mendidik mereka. Hendaknya kedua orang tua mendidik mereka dengan penuh cinta dan kasih sayang. Welas asih, mengetahui kewajiban syariat mereka dalam mendidik anak tanpa kekerasan (Al-Falsafì, 2017).

d. Lingkungan pendidikan

Faktor yang mempengaruhi perkembangan kejujuran anak adalah lingkungan tempat tinggalnya. Ketika kedua orang tua senantiasa jujur dengan meninggalkan kebohongan, maka anak akan berbicara dengan cara yang benar dan istiqomah. Serta sangat mudah sekali menghilangkan rintangan yang ada dalam dirinya (Al-Falsafí, 2017).

Dari pemikiran Muhammad Taq̄̄ al-Falsafī di atas, menurut hemat penulis sangat relevan dengan fenomena sifat generasi pemuda di beberapa negara. Penelitian yang dilakukan 
Al Athfaal: Jurnal Ilmiah Pendidikan Anak Usia Dini

Vol.4 No.1 (2021) 106-123

p-ISSN : 2622-5484

http://ejournal.radenintan.ac.id/index.php/al-athfaal

e-ISSN : 2622-5182

Juni 2021

oleh Alain Cohn, dkk negara yang menduduki posisi teratas dalam hal kejujuran adalah Swiss.

Kemudian disusul oleh Norwegia, Belanda, Denmark, Swedia dan negara lainnya. Indonesia menduduki posisi 33 dari 40 negara (Cohn \& Tannenbaum, 2019). Selain itu, berdasarkan data yang dikeluarkan oleh KPK, tingkat kejujuran di Indonesia tergolong rendah. Ini dibuktikan dengan kasus korupsi yang terjadi sejak tahun 2004-2018 di Indonesia (Jiwandono et al., 2020).

3. Memuliakan kepribadian anak

Muhammad Taqī al-Falsafī menjelaskan:

"Prilaku seluruh individu manusia antara satu dan lainnya bisa dilihat bagaimana model pendidikan yang dijadikan pada masa anak masih kecil di dalam keluarga atau guru di sekolah. Baik buruk yang mereka temui sejak kecil mendarah daging sampai mereka dewasa dan mereka menjadi anggota masyarakat. Dengan kata lain, tindak tanduk manusia setiap generasi merupakan hasil dari benih pendidikan yang mempengaruhi otak mereka sejak kecil. Kepribadian, kebebasan dan percaya diri, begitu sebaliknya hinaan, tidak percaya diri, kekerasan, dan sifat yang menjadi kebiasaan mereka. Kedua orang tualah yang membentuk kepribadian mereka sejak kecil. Anak yang tumbuh di lingkungan keluarga yang penuh kekerasan dan hinaan, tidak berinteraksi secara manusiawi, tidak diakui sebagai anggota keluarga yang terhormat, maka ketika ia besar tidak mampu menampakkan kebebasan dalam kepribadiannya. Dia tidak mampu melihat dirinya diberi tanggung jawab yang membebaninya, tidak mampu sama sekali melihat kepribadiannya. Keberadaanya merupakan nasib sial. Sangat tidak mudah menghilangkan merubahnya. Pendidikan yang benar dan menumbuhkan sifat mulia pada anak yaitu menyempurnakan model dan eksprimen yang tepat saja. Kedua orang tua wajib mengakomodir itu, mengikuti rentak anak langkah demi langkah, mencoba mempraktikkan model tersebut. Keluarga yang mengabaikan ini sesungguhnya ia lemah dalam melaksanakan pendidikan yang benar terhadap anak (Al-Falsafì, 2017)”.

Menjaga harga diri merupakan tuntutan dalam ajaran Islam. Hāfizh Hasan al-Mas'udi berpendapat bahwa menjaga harga diri merupakan sifat yang mengajak kepada berpegang teguh pada akhlak yang mulia. Penyebabnya adalah cita-cita yang tinggi, diri yang mulia. Jika mempunyai cita-cita yang tinggi dan diri yang mulia, maka tujuannya menjaga kemuliaan, menemukan keutamaan, membina kemuliaan, mengorbankan pemberian dan mencegah penyakit (Al-Mas'udi, n.d.).

Agar kehormatan dan harga diri anak terjaga, Muhammad 'Athiyyah al-Abrāsȳ̄ mengulas pandangan Abd al-Malik bin Marwān, ia menjelaskan bahwa jika engkau ingin 
Al Athfaal: Jurnal Ilmiah Pendidikan Anak Usia Dini

Vol.4 No.1 (2021) 106-123

p-ISSN : 2622-5484

http://ejournal.radenintan.ac.id/index.php/al-athfaal

e-ISSN : 2622-5182

Juni 2021

menegur, mendidik dan menghukumi anak, maka usahakan semampun mungkin agar perlakuan tersebut dilakukan secara tersembunyi dan tidak diketahui oleh orang yang akan membocorkan rahasia tersebut, dan menyebarkannya. Tujuannya agar menjaga harga diri anak, dan ia tidak direndahkan oleh siapapun (al-Abrāsȳi, 1961).

Di samping itu, memuji dan memotivasi anak juga diperlukan agar anak menjadi lebih percaya diri. Bukan dengan menghina. Ibnu Miskawih menjelaskan, hendaknya anak dipuji atas kebaikan yang dilakukannya dan memuji sesuatu yang bagus yang diperlihatkannya (Miskawih, 1985). Pendapat ini senada yang dikatakan oleh Ahmad Susanto dalam bukunya "Perkembangan Anak Usia Dini" sebagaimana yang dikutip oleh Elisabeth Dyah Ayu Permatasari bahwa teknik membangun rasa percaya diri pada anak dengan memuji usaha anak (Permatasari, 2016).

Dari pendapat-pendapat diatas, dapat disimpulkan bahwa betapa pentingnya memuji seorang anak dalam mendidik. Muhammad Taqī al-Falsafī sudah mengingatkan hal tersebut.

4. Menumbuhkan keimanan pada diri anak

Muhammad Taqī al-Falsafī berkomentar beliau:

"Sesungguhnya anak yang didik dengan asas keimanan sejak kecil akan menjadi istimewa dengan keinginan yang kuat dan semangat. Akan tampak pada dirinya tanda-tanda murah hati dan cerdas sejak kecil. Ia mampu mengungkapkan katakata yang bersih dan jelas. Ruh anak dalam menerima pendidikan agama dan akhlak bagaikan tanah yang subur yang menerima benih di dalamnya. Oleh sebab itu, kedua orang tua harus segera menanam benih keimanan dan keutamaan dalam diri anak, jangan sampai terlewatkan kesempatan tersebut. Otomatis seorang guru juga harus segera menumbuhkan anak dengan pendidikan kegamaan yang baik (AlFalsafî, 2017)

Musthafa al-Ghalāyaini mencoba mengulas bahwa tujuan pendidikan sejatinya bagaikan "menanamkan" akhlak di dalam diri anak dan "menyiraminya" dengan "air" petunjuk dan nasihat. Sehingga mengakar pada diri anak. Kemudian menghasilkan keutamaan, kebaikan dan mencintai amal untuk kemanfaatan tanah air (Al-Ghalāyaini, 1953). Muhammad Sa’̄̄d Mursī menekankan pentingnya habituasi pendidikan ibadah terhadap anak, beliau menyatakan ketika anak tidak dibiasakan dengan shalat sebagai contoh, sejak kecil, maka ia akan merasakan sangat berat ketika dewasa. Barangsiapa yang tidak terbiasa membaca al- 
Al Athfaal: Jurnal Ilmiah Pendidikan Anak Usia Dini

Vol.4 No.1 (2021) 106-123

p-ISSN : 2622-5484

http://ejournal.radenintan.ac.id/index.php/al-athfaal

e-ISSN : 2622-5182

Juni 2021

Qur'an sejak kecil, maka akan terasa berat membawa mushaf, apalagi membacanya ketika sudah dewasa. Maka biasakanlah beribadah (M. S. Mursī, 1998). Berkaitan dengan pendidikan keimanan, penelitian yang dilakukan oleh Warsah menjelaskan bahwa pendidikan keimanan merupakan salah satu pondasi utama dalam penilaian keberhasilan pendidikan dan kesalehan anak. Dengan itu anak diharapkan menjadi manusia yang beriman (melaksanakan segala perintah-Nya dan menjauhi segala larangan-Nya). Pada akhirnya, diri anak akan terbentengi dari perbuatan dan kebiasaan buruk. (Warsah, 2018). Sejatinya Muhammad Taqī al-Falsafī sudah lama mengingatkan pentingnya menumbuhkan pendidikan keimanan pada diri anak.

Di dalam surah Attahrim, ayat 6, tanggung jawab ayah mempunyai tanggung jawab untuk mendidik keluarga agar terhindar dari siksaan api neraka. Menurut Muhamad al-Thāhir ibn 'Âsyūr, ungkapan agar waspada menjaga dari api neraka tersebut merupakan sebuah majas. Karena nasihat dapat menjauhi dari perkara yang mengakibatkan azab api neraka (Ibn 'Âsyūr, 1984).

5. Tidak berlebihan dalam mencintai anak

Muhammad Taqī al-Falsafī menjelaskan:

"Sesungguhnya anak yang diberikan cinta dan kasih sayang yang berlebihan, kedua menyerahkan segalanya tanpa ada persyaratan, memenuhi segala permintaan mereka baik yang bagus maupun tidak, selanjutnya memiliki sikap sewenangwenang dan terlalu membanggakan diri, mereka itu memiliki ruh yang lemah dan jiwa yang cepat menyerah terhadap tantangan. Mereka terpengaruh terhadap sikap kekanak-kanakan sampai mereka dewasa dalam menghadapi perkara yang sangat sederhana. Mereka sangat cepat menyerah dalam menghadapi problematika kehidupan. Seluruh model pendidikan yang membingungkan, yang diterapkan oleh kedua orang tua dalam mendidik anak terkadang mempunyai pengaruh buruk. Ia dilahirkan dari kekeliruan. Terlalu mencintai anak merupakan kesalahan terbesar dalam pendidikan. Akibat buruk yang ditemui oleh anak sangat berbahaya. Para pakar psikologi banyak membahas topik ini dalam pendidikan. Setiap mereka telah mencoba merinci pembahasan tersebut (Al-Falsafì, 2017).”

Rasulullah SAW sudah mempraktikkan kasih sayang terhadap anak. Bukti tersebut terekam dalam hadits al-Muslim sebagai berikut:

Artinya: "Menceritakan kepadaku Amru al-Nāqid dan Ibn Abī Umar, semuanya dari Sufyān, Amru berkata: Diceritakan kepada kami oleh Sufyān bin 'Uyainah dari al-Zuhrī dari 
Al Athfaal: Jurnal Ilmiah Pendidikan Anak Usia Dini

Abī Salamah dari Abī Hurairah bahwasasnya al-'Aqra' bin Hābis melihat nabi Muhammad SAW mencium al-Hasan. Kemudian berkata: "Aku mempunyai 10 orang anak, tidak seorangpun dari mereka yang pernah kucium." Maka Rasulullah SAW bersabda: "Barangsiapa yang tidak menyayangi maka ia tidak akan dirahmati” (Al-Naisābūrī, 2006).

Menurut Thomas Lickona, cinta membuat anak merasa aman, signifikan, dan berharga. Ketika merasa dicintai, mereka menjadi terikat secara secara emosional kepada kita. Keterikatan itu membuat mereka lebih responsive terhadap otoritas dan menerima nilai-nilai kita (Lickona, 2012).

Ahmad Tafsir mencoba menganalisis lebih dalam mengenai dampak buruk terlalu mencintai anak. Beliau menjelaskan:

"Cinta kepada anak menyebabkan orang lupa kepada Allah dan Rasul-Nya. Mereka sibuk mengurus anak-anaknya. Mereka bekerja mati-matian untuk mencari uang agar semua permintaan anaknya dapat dipenuhi, ya, cinta kepada anak. Kadangkadang permintaan yang tidak masuk akal pun dipenuhi, demi cinta kepada anak. Sayang anak menyebabkan orang korupsi atau mencuri. Semuanya itu menyebabkan orang dapat lupa kepada Allah dan Rasul-Nya. Orang tua juga dapat menjadi budak anaknya; ia merasa wajib memenuhi segala keinginan anaknya, seperti dikatakan di atas sampai ia kalah oleh anaknya karena terlambat atau tidak mampu memenuhi permintaan anaknya (Tafsir, 2013).”

Penelitian yang diperoleh Hamid Masud, dkk melalui 34 studi yang dilakukan, menunjukkan bahwa gaya pengasuhan memiliki dampak langsung pada sifat agresi anak-anak. Gaya pengasuhan yang otoritatif memainkan peran positif dalam perilaku psikologis pada anakanak sementara gaya pengasuhan yang otoriter dan permisif menghasilkan perilaku agresif dan negatif pada anak-anak (Masud et al., 2019). Menurut Elizabeth B. Hurlock, orang tua yang sangat khawatir atau sangat menonjolkan diri akan mendorong bayi untuk memusatkan perhatian kepada dirinya sendiri dan menjadi terikat pada diri sendiri serta mementingkan diri sendiri. Dengan demikian bayi mengharapkan agar orang lain memberikan kasih sayang tetapi ia tidak membalas memberi kasih sayang kepada orang lain(Hurlock, 1999). Dengan demikian, pola asuh dengan gaya primisif dan terlalu berlebihan dalam menyayangi anak berakibat buruk pada diri anak. Muhammad Taqī al-Falsafì sudah mengingatkan tentang hal ini dalam kitabnya tersebut. 
Al Athfaal: Jurnal Ilmiah Pendidikan Anak Usia Dini

Vol.4 No.1 (2021) 106-123

p-ISSN : 2622-5484

http://ejournal.radenintan.ac.id/index.php/al-athfaal

e-ISSN : 2622-5182

Juni 2021

\section{SIMPULAN DAN SARAN}

Simpulan dari penelitian ini adalah menurut pemikiran Muhammad Taqī al-Falsafì dalam buku al-Thifl Baina al-Waratsah wa al-Tarbiyah dapat dirumuskan mengenai peran orang tua dalam mendidik anak menjadi 5 peran: (a) jangan mengingkari janji dengan anak, (b) melatih anak untuk bersikap jujur (c) memuliakan kepribadian anak, (c) menumbuhkan keimanan pada diri anak dan (d) tidak berlebihan dalam mencintai anak. Dari pemikirannya tersebut peneliti menemukan bahwa pemikiran Muhammad Taqī Al-Falsafī masih relevan untuk pendidikan anak saat ini.

Berdasarkan dari uraian di atas, maka dapat diberikan beberapa saran diantaranya : (a) penelitian diharapkan mampu melihat perbandingan tentang pendidikan anak dalam pandangan tokoh Syiah, (b) pemikiran Muhammad Taqī al-Falsafī yang terlihat sederhana, akan tetapi di negara yang maju sudah menerapkan konsep tersebut dan menjadi negara yang rendah tingkat criminal. Oleh sebab itu, untuk membentuk karakter bangsa yang baik harus dimulai dengan pendidikan anak. Artinya, penulis menyarankan agar peneliti selanjutnya bisa membandingkan tokoh Syiah ini dengan tokoh-tokoh Sunni yang lain untuk melihat lebih jauh persamaan dan perbedaan pendapat mengenai pendidikan anak.

\section{UCAPAN TERIMA KASIH}

Terima kasih kami ucapkan kepada Jurnal Al-Athfaal: Jurnal Ilmiah Pendidikan Anak Usia Dini UIN Raden Intan Lampung yang telah bersedia menerbitkan tulisan ini.

\section{DAFTAR PUSTAKA}

A’yun, Q., Prihartanti, N., \& Chusniatun. (2015). Peran Orangtua dalam Pendidikan Anak Usia Dini (Studi Kasus pada Keluarga Muslim Pelaksana Homeschooling). Jurnal Indigenous, 13(2), 3340 .

al-Abrāsȳī, M. 'Athiyyah. (1961). al-Tarbiyyah fi al-Islam. al-Majlis al-A'la li al-Syu'ūn alIslāmiyyah bi Wizārah al-Awqāf.

Al-Bukhārī, A. A. M. bin I. (1979). al-Jāmi’ al-Shahīh. al-Mathba'ah al-Salafiyyah.

Al-Falsafī, M. T. (2017). Al-Thifl Baina Al-Waratsah Wa Al-Tarbiyah (F. al-H. Al-Mīlānī (Ed.)). Dār al-Ta'āruf li al-Mathbū'āt.

Al-Ghalāyaini, M. (1953). 'Izzah al-Nāsyi 'īn. al-Maktabah al-'Ashriyyah li Thaba'ah wa al-Nasyr. Al-Ghazālī, A. H. M. bin M. bin M. bin A. (2011). Ihya’ Ulum al-Din. Dar al-Minhaj. 
Al Athfaal: Jurnal Ilmiah Pendidikan Anak Usia Dini

Vol.4 No.1 (2021) 106-123

http://ejournal.radenintan.ac.id/index.php/al-athfaal

p-ISSN : 2622-5484

e-ISSN : 2622-5182

Juni 2021

Al-Mas’udi, H. H. (n.d.). Taysir al-Khalāq. Maktabah al-'Alawiyyah.

Al-Naisābūrī, A. al-H. M. bin al-H. al-Q. (2006). Shahīh Muslim (A. Q. N. M. Al-Faryābī (Ed.)). Dār Thayyibah.

Alonso-Stuyck, P. (2019). Which parenting style encourages healthy lifestyles in teenage children? Proposal for a model of integrative parenting styles. International Journal of Environmental Research and Public Health, 16(11). https://doi.org/10.3390/ijerph16112057

Boeree, C. G. (2017). General Psychology; Psikologi Kepribadian, Persepsi, Kognisi, Emosi, \& Perilaku. Prismashopie.

Cohn, A., \& Tannenbaum, D. (2019). Civic honesty around the globe. 73(July), 70-73.

Dantes, N. (2012). Metode Penelitian. Andi Offset.

Falsafi, M. T. (2020). Biografi Mohammad Taghi Falsafi. https://en.wikipedia.org/wiki/Mohammad_Taghi_Falsafi

Hasiana, I. (2020). Peran Orangtua Dalam Pendidikan Seksual Anak Usia Dini. Wahana, 72(2), 118125. https://doi.org/10.36456/wahana.v72i2.2725

Hoskins, D. (2014). Consequences of Parenting on Adolescent Outcomes. Societies, 4(3), 506-531. https://doi.org/10.3390/soc4030506

Hurlock, E. B. (1999). Psikologi Perkembangan; Suatu Pendekatan Sepanjang Rentang Kehidupan (Istiwidayanti dan Soedjarwo (Ed.)). Penerbit Erlangga.

Ibn ‘Âsyūr, M. al-T. (1984). Tafsīr al-Tahrīr wa al-Tanwīr. Dār al-Tūnisiyyah li al-Nasyr.

Jailani, M. S. (2014). Teori Pendidikan Keluarga dan Tanggung Jawab Orang Tua dalam Pendidikan Anak Usia Dini. Nadwa, 8(2), 245. https://doi.org/10.21580/nw.2014.8.2.580

Jiwandono, I. S., Setiawan, H., Witono, A. H., \& Hazmi, H. Y. (2020). Program Pemberdayaan Anak Penyintas Gempa Lombok. 3(3), 535-542.

Kanngiesser, P., Köymen, B., \& Tomasello, M. (2017). Young children mostly keep, and expect others to keep, their promises. Journal of Experimental Child Psychology, 159, 140-158. https://doi.org/10.1016/j.jecp.2017.02.004

Kurniati, E., Nur Alfaeni, D. K., \& Andriani, F. (2020). Analisis Peran Orang Tua dalam Mendampingi Anak di Masa Pandemi Covid-19. Jurnal Obsesi : Jurnal Pendidikan Anak Usia Dini, 5(1), 241. https://doi.org/10.31004/obsesi.v5i1.541

Lickona, T. (2012). Character Matters Persoalan Karakter; Bagaimana Membantu Anak Mengembangkan Penilaian yang Baik, Integritas, dan Kebajikan Penting Lainnya (A. W. \& J. A. R. Zien (Ed.)). PT. Bumi Aksara.

Ma'luf, L. (2017). al-Munjid Madrasiy li al-Lughah al- 'Arabiyah. Al-Thaba'ah al-Katolikiyah.

Mansur. (2014). Pendidikan Anak Usia Dini dalam Islam. Pustaka Pelajar.

Manzur, I. (n.d.). Lisan al- 'Arab. Dar al-Ma'arif.

Masud, H., Ahmad, M. S., Cho, K. W., \& Fakhr, Z. (2019). Parenting Styles and Aggression Among Young Adolescents: A Systematic Review of Literature. Community Mental Health Journal, 55(6), 1015-1030. https://doi.org/10.1007/s10597-019-00400-0

Miskawih, I. (1985). Tahzīb al-Akhlāq fi al-Tarbiyyah. Dar al-Kutub al-'Ilmiyyah.

Mursī, M. M. (1987). Al-Tarbiyyah al-Islāmiyyah; Ushūluha wa Tathawwurruha fi al-Bilād al'Arabiyyah. Dār al-Ma'ārif.

Mursī, M. S. (1998). Fann al-Tarbiyyah al-Awlad fi al-Islam. Dār al-Tawzi' wa al-Nasyr.

Nawwāb, A. al-R. N. al-D. Â. (2002). Mas'uliyah al-Âbā' Tujāh al-Awlād. Kementerian Urusan 
Islam, Wakaf, Dakwah dan Penyuluhan.

Papalia, Diane E., et. al. (2008). Human Development (Psikologi Perkembangan) (A. K. Anwar (Ed.)). Kencana.

Permatasari, E. D. ayu. (2016). Meningkatkan Rasa Percaya Diri Pada Anak Usia 4-5 Tahun Melalui Gerak Dan Lagu. Universitas Slamet Riyadi, 1(18), 71-78.

Prawira, P. A. (2017). Psikologi Kepribadian dengan Perspektif Baru. Ar-Ruzz Media.

Undang-undang RI Nomor 35 Tahun 2014 Tentang Perlindungan anak, (2014) (testimony of Republik Indonesia).

Saleh, M. N. I. (2015). Perbandingan Sistem Pendidikan di Tiga Negara; Mesir , Iran dan Turki. Jurnal Pendidikan Islam, 4(1), 49-70.

Setoh, P., Zhao, S., Santos, R., Heyman, G. D., \& Lee, K. (2019). Dataset on childhood exposure to parenting by lying and its associations with adulthood psychosocial outcomes in a Singapore sample. Data in Brief, 26, 104472. https://doi.org/10.1016/j.dib.2019.104472

Sunarty, K. (2016). Hubungan Pola Asuh Orangtua Dan Kemandirian Anak. Journal of Educational Science and Technology (EST), 2(3), 152. https://doi.org/10.26858/est.v2i3.3214

Sutarman, M. dan A. (2016). Manajemen Pendidikan Usia Dini; Filosofi, Konsep, Prinsip, dan Aplikasi. CV Pustaka Setia.

Tafsir, A. (2013). Ilmu Pendidikan Islam. PT. Remaja Rosdakarya Offset.

TV, A. (2018). Lebih dari setengah juta mahasiswa asing belajar di Iran.

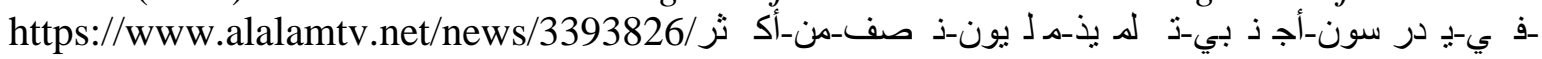
إي ران

Umar, M. (2015). Peranan Orang Tua Dalam Peningkatan Prestasi Belajar Anak. JURNAL EDUKASI: Jurnal Bimbingan Konseling, 1(1), 20. https://doi.org/10.22373/je.v1i1.315

Warsah, I. (2018). Pendidikan Keimanan Sebagai Basis Kecerdasan Sosial Peserta Didik: Telaah Psikologi Islami. Psikis: Jurnal Psikologi Islami, 4(1), 1-16. https://doi.org/10.19109/psikis.v4i1.2156

Warsono, W. (2017). Guru: Antara Pendidik, Profesi, Dan Aktor Sosial. The Journal of Society \& Media, 1(1), 1. https://doi.org/10.26740/jsm.v1n1.p1-10 